\title{
Interaction Between some Phenolic Compounds in Ammi majus Herb (Khillah) Extracts and Antibiotics Against some Selected Bacterial Isolates In vitro
}

\author{
Kawthar A. Al-Hadidi \\ Department of Clinical \\ Laboratory Science \\ College of Pharmacy \\ University of Mosul \\ Kawtharhadidi@yahoo.com
}

\author{
Adeeba Y.Al-Numan \\ Department of Biology \\ College of Science \\ University of Mosul
}

\author{
Ayad C. Al-Daody \\ Department of Biology \\ College of Education \\ University of Mosul
}

(Received 28/6/2012; Accepted 7/11/2012)

\begin{abstract}
In this study, the in vitro activities of eight phenolic compounds (xanthotoxin, imperatorin, quercetin, hydroquinone, catechol, resorcinol, salicylic acid and vanillic acid) in the petroleum ether and ethanolic extracts of Ammi majus (Khillah) herb and five antibiotics (penicillin, ampicillin, cefotaxime, cephalothin and trimethoprim) against two Gram positive bacteria (Staphylococcus aureus and Staphylococcus epidermidis) and three Gram negative bacteria (Escherichia coli, Proteus mirabilis and Proteus vulgaris) alone and in combination are evaluated. Among the seven Ammi majus extracts, the extract (No.7) which contain salicylic acid, resorcinol and quercetin in high concentration showed stronger inhibitory activity against all the bacterial isolates studied with inhibition zones in the range of (16-23) $\mathrm{mm}$. Staphylococcus aureus and Staphylococcus epidermidis were reported to show sensitivity to trimethoprim, ampicillin, penicillin and cephalothin respectively with inhibition zones in the range of (10.5-23) $\mathrm{mm}$ and resistance to cefotaxime. While Escherichia coli, Proteus mirabilis and Proteus vulgaris are more resistant to all the antibiotics used. The best synergistic interactions showed trimethoprim and ampicillin with all Ammi majus extracts against Staphylococcus aureus and with all extracts (except with extract No.7) against Staphylococcus epidermidis, and (ampicillin, trimethoprim, cephalothin), (cephalothin, ampicillin), (cephalothin only) with some Ammi majus extracts against Proteus vulgaris, Escherichia coli and Proteus mirabilis respectively. Hydroquinone enhance the activity of ampicillin against Escherichia coli, while vanillic acid inhibit the activity of cephalothin against Escherichia coli and Proteus mirabilis. Staphylococcus aureus followed by Staphylococcus epidermidis and Proteus vulgaris were the most sensitive microbes to most of the combinations.
\end{abstract}

Keywords: Interaction, phenolic compounds, Ammi majus extracts, antibiotics, Gram positive bacteria, Gram negative bacteria. 


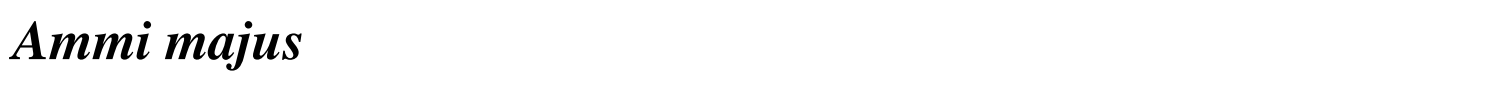 والمضادل الحيوية ضد عددمن العزلات الجرثومية المنقاة خارج الجمم}

\section{الملغص}

تضمنت الدرلسة قدير الفعالية ضد الجرثومية (خارج الجسم) لثماني مركبلت فينولية وهي



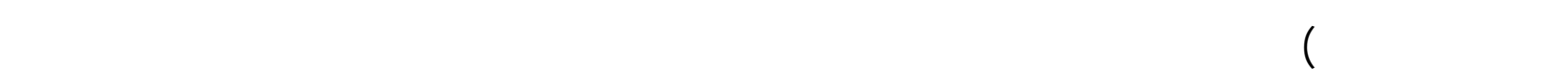

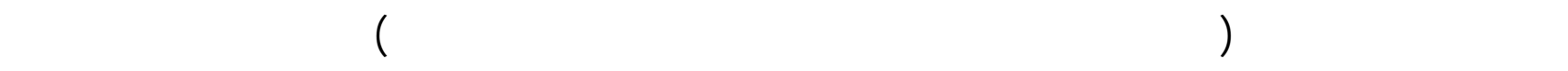

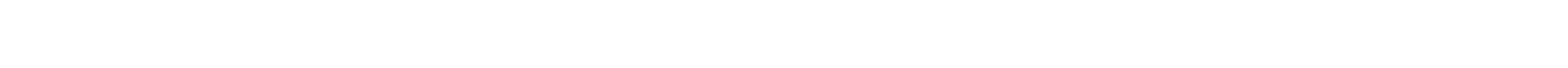
vulgaris mirabilis

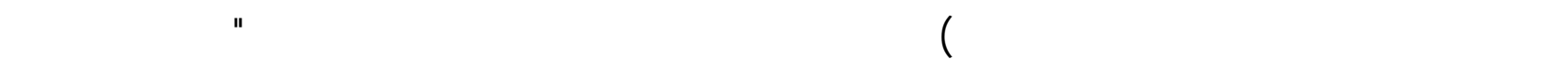



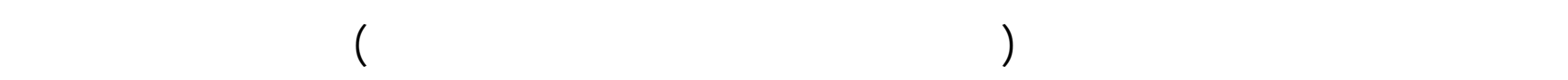

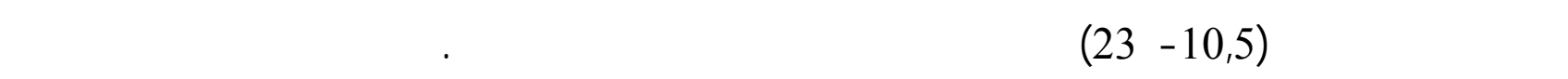

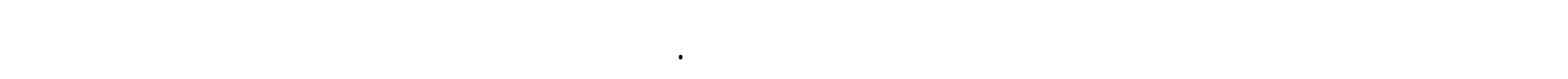
المضابن الحيويين تراي ميثبريم و لمبسلين مع كل مستخلصت عشبة الخلة ضد المكورات العقودية الذهبية ومع كل المستخلصت (بلستثناء المستخلص رقم 7) ضد المكورات العقوية البثروية، والمضادات الحيوية

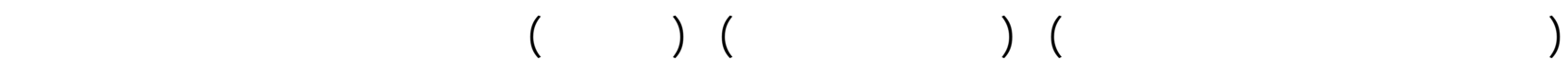

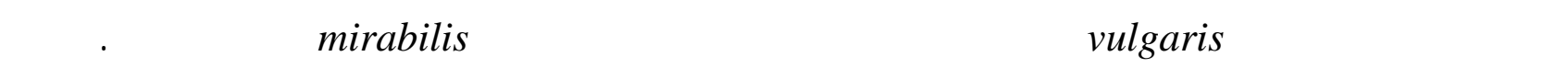

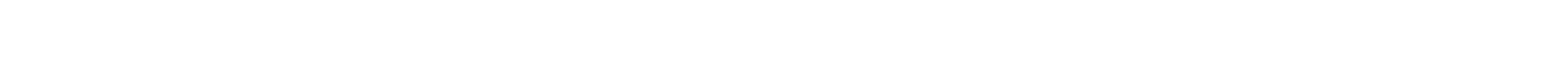

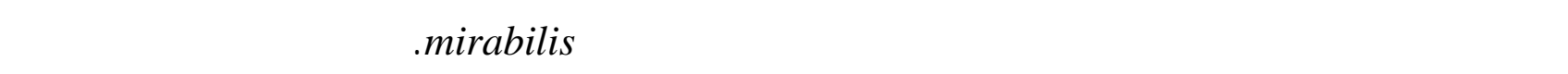

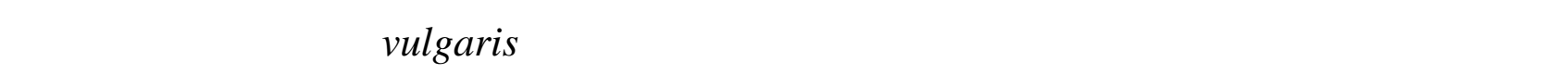
لغالبية التدلخلات.

\section{INTRODUCTION}

With increased incidence of resistance to antibiotics, natural products from plants could be interesting alternatives (Lu et al., 2007). Some plant extracts and phytochemicals are known to have antimicrobial properties, and can be of great significance in therapeutic treatments (Singh et al., 2007).

Many plants have been evaluated not only for direct antimicrobial activity, but also as a resistance-modifying agent (Gibbons, 2004). Several chemical compounds, synthetic or from natural sources, such as natural products, have direct activity against many species of 
bacteria, enhancing the activity of a specific antibiotic, reversing the natural resistance of specific bacteria to given antibiotics, promoting the elimination of plasmids from bacteria and inhibiting transport functions of the plasma membrane in regard to given antibiotics. The inhibition of plasma membrane - based efflux pumps has been observed as well (Gunics et al., 2006).

Synergism has been defined as a phenomenon in which two different compounds are combined to enhance their individual activity. If the combination results in worsening effect, it is called antagonism. Effect which is less than synergistic but not antagonistic is termed as additive or indifference (Rani et al., 2009).

Ammi majus belongs to the family Apiaceae, commonly called as "Ladies Lace". The plant is used for the treatment of leukoderma and psoriasis (Kumar, 1988). The constituents (xanthotoxin, imperatorin, isopimpinellin, bergapten and isoimperatorin) isolated from the seeds are used to prepare cream and lotion to cure skin diseases. The isoimperatorin is the strongest photoirritant compound (Saeed and Khan, 1994). The leaves contain furocoumarins fraction is composed of xanthotoxin and isopimpinellin. The presence of nonfurocoumarin, umbelliprenin, glycosides of quercetin, luteolin, dihydro oroselone and two artifacts 7- inopropylpsoralene are reported (Anonymous, 1985). Recently, the drug $\beta$ methoxypsoralen from Ammi majus is used to treat T-cell lymphoma (Gurib-Fakim, 2006).

Staphylococci are among the most common cause of bacterial infections in the community, which have been, and continue to be a major cause of human disease resulting in over than one million infections each year worldwide. Staphylococcus aureus is the best known and by far most studied staphylococcal species that produces hospital - and community - acquired infections (Bancroft, 2007). Staphylococcus epidermidis is the sister species of Staphylococcus aureus, which often causes infection in immunocompromised individuals or those after damage to the epithelium. Similar to Staphylococcus aureus, it produces biofilm to protect itself from host immune system and enhance their resistance to antibiotic chemotherapy (Stewart and Costerton, 2001).

Escherichia coli, the most common member of the family Enterobacteriaceae implicated in urinary tract infections, has showed increasingly resistance to antibiotics and caused some therapeutic problems (Sotto et al., 2001).

Proteus mirabilis and to a lesser extent Proteus vulgaris, are common inhabitants of the human gastrointestinal tract. Proteus mirabilis, in particular, also may colonize the urinary tract under certain circumstances, where it is considered an opportunistic pathogen and one of the principal causes of UTIs in hospital patients with indwelling urinary catheters (Manos and Belas, 2006) and it's known for its ability to form crystalline biofilms on the outer surface and in the lumen of indwelling urinary catheters (Mobley and Warren, 1987). Biofilm-forming bacterium constitutes a major medical problem because of the sharply decreased susceptibility of bacteria, within the biofilm, to host defenses and antibiotic treatments. Standard antibiotic therapy is only able to eliminate the planktonic and the superficial cells in biofilm leaving the deeply embedded sessile cells propagating within the biofilm and continue to disseminate when the therapy is terminated (Olson et al., 2002).

The aims of the present study were to evaluate the antimicrobial activity of eight phenolic compounds (xanthotoxin, imperatorin, quercetin, hydroquinone, catechol, resorcinol, salicylic acid and vanillic acid) in the petroleum ether and ethanolic extracts of Ammi majus (Khillah) herb and compare them to the effect of antibiotics (penicillin, 
ampicillin, cefotaxime, cephalothin and trimethoprim) on the growth of (Staphylococcus aureus, Staphylococcus epidermidis, Escherichia coli, Proteus mirabilis and Proteus vulgaris); and to evaluate the interaction of the phenolic compounds and antibiotics on these bacterial isolates.

\section{MATERIALS AND METHODS}

\section{Plant extracts preparation Petroleum ether extract:}

One hundred fifty gram of Ammi majus plant was grounded and extracted with (750) $\mathrm{ml}$ of petroleum ether $\left(60-80^{\circ} \mathrm{C}\right)$ for $(48)$ hours using magnetic stirrer at room temperature. The extract was filtered using a Whatmann (No.1) filter paper and then evaporated under reduced pressure using a rotator evaporator to a volume of (60) $\mathrm{ml}$ and this concentration was regarded as crude extract.

The crude extract was divided into three parts:

\section{a) Crude Extract (20 ml):}

It was kept in the refrigerator till used, this extract was evaporated again and its antibacterial effect was studied (extract No.1).

b) The Second Portion (20 ml):

It was incubated in freezer for (24) hours, then filtered and the sediment was used as (extract No.2). The filtrate was dried and used as (extract No.3), (Tsankova et al., 1993).

c) The Third Portion $(20 \mathrm{ml})$ :

It was dried then added to it (20) $\mathrm{ml}$ of absolute ethanol and left in freezer for (24) hours, filtered and the sediment was used as (extract No.4). The filtrate was dried and used as (extract No.5), (Morimoto et al., 1965).

\section{Ethanolic Extract:}

The remaining plant material was dried from petroleum ether and extracted again with (750) $\mathrm{ml}$ of absolute ethanol by using a magnetic stirrer for (48) hours with stirring. The extract was then filtered (white material was obtained in the filtrate, filtered and used as extract No.6). The filtrate was concentrated using a rotator evaporator to a volume of (40) $\mathrm{ml}$ which was then subjected to acid hydrolysis for the isolation of phenolic compounds (Grand et al., 1988).

\section{Acid Hydrolysis:}

1) $20 \mathrm{ml}$ of $(1 \mathrm{~N}) \mathrm{HCL}$ was added to (1) $\mathrm{ml}$ of crude ethanolic extract in flask warmed at $\left(90{ }^{\circ} \mathrm{C}\right)$ for half an hour.

2) After cooling, $(2 \times 15) \mathrm{ml}$ ethyl acetate was added, the mixture was transformed to separating funnel for isolation of phenolic compounds. Ethyl acetate was isolated, stored in refrigerator and was regarded as (extract No.7), (Harborne, 1973).

\section{Test Antibiotics:}

Five commercial antibiotics (ampicillin, penicillin, cefotaxime, cephalothin and trimethoprim) were selected. 


\section{Test Organisms:}

The bacteria used in the antibacterial tests were: Gram positive (Staphylococcus aureus and Staphylococcus epidermidis) and Gram-negative (Escherichia coli, Proteus mirabilis and Proteus vulgaris). All bacteria were clinical isolates classified in the Laboratory of Microbiology / Department of Biology / College of Science / University of Mosul.

\section{Ammi majus Extracts Sensitivity Testing:}

The selected isolates of bacteria were inoculated into (5) $\mathrm{ml}$ of sterile nutrient broth and incubated at $\left(37^{\circ} \mathrm{C}\right)$ for $(6-8)$ hours. The density of the tested suspensions were adjusted to that of the (0.5) McFarland standard. Using a sterile cotton swab, the nutrient broth cultures was swabbed on the surface of sterile Mueller-Hinton Agar (MHA) plates. Agar wells were prepared with the help of sterilized cork borer with (6) mm diameter (Srinivasan et al., 2001). Using a micropipette, (50) microlitres of each of Ammi majus extracts (all the extracts were dried and re-dissolved in DMSO at concentration of $1 \mathrm{~g} / 5 \mathrm{ml}$ ) were added to different wells in the plate. The plates were incubated in an upright position at $\left(37^{\circ} \mathrm{C}\right)$ for (24) hours. The diameter of inhibition zones was measured in $\mathrm{mm}$ and the results were recorded.

\section{Antibiotics Sensitivity Testing:}

The formerly mentioned microorganisms were also tested for their sensitivity to the antibiotics: penicillin (10 U), ampicillin (10 mcg), cefotaxime (10 mcg), cephalothin (30 $\mathrm{mcg})$ and trimethoprim (10 mcg) by the disk diffusion method (Bauer et al., 1966). The cultures were seeded in sterile nutrient broth at $\left(37^{\circ} \mathrm{C}\right)$ for $(6-8)$ hours. The density of the tested suspensions were adjusted to that of the (0.5) McFarland standard. Using sterile cotton swabs, the cultures was aseptically swabbed on the surface of sterile Mueller-Hinton Agar (MHA) plates. Using an ethanol dipped and flamed forceps, the antibiotic discs were aseptically placed over the seeded MHA plates sufficiently separated from each other to avoid overlapping of the inhibition zones. The plates were incubated at $\left(37^{\circ} \mathrm{C}\right)$ for $(24)$ hours and the diameter of the inhibition zones was measured in $\mathrm{mm}$.

\section{Interaction between Ammi majus Extracts and Antibiotics Sensitivity Testing:}

The inocula from primary cultures were prepared in nutrient broth and incubated at $\left(37^{\circ} \mathrm{C}\right)$ for $(6-8)$ hours. The density of the tested suspensions was adjusted to that of the (0.5) McFarland standard. Muller-Hinton agar plates were inoculated by dipping a sterile cotton swabs in the inocula. The antibiotic discs were placed as mentioned formerly (Srinivasan et al., 2001). Later (10) $\mu \mathrm{L}$ (or $30 \mu \mathrm{L}$ in case of cephalothin) of each of Ammi majus extracts were aseptically added to these discs. The plates were incubated in an upright position at $\left(37^{\circ} \mathrm{C}\right)$ for $(24)$ hours. The diameter of inhibition zones were measured in $\mathrm{mm}$ and the results were recorded.

\section{RESULTS AND DISCUSSION}

The present study explored the antimicrobial activities of eight phenolic compounds (xanthotoxin, imperatorin, quercetin, hydroquinone, catechol, resorcinol, salicylic acid and vanillic acid) in seven extracts (extract No.1- extract No.7) from Ammi majus alone, five antibiotics alone (penicillin, ampicillin, cefotaxime, cephalothin and trimethoprim) and 
interaction between them against five isolates (Staphylococcus aureus, Staphylococcus epidermidis, Escherichia coli, Proteus mirabilis and Proteus vulgaris) of pathogenic bacteria.

Phytochemical screening of Ammi majus extracts has shown the presence of (xanthotoxin / $51.749 \%$, imperatorin / $0.091 \%$, quercetin / $0.103 \%$, resorcinol / $0.268 \%$, salicylic acid / $0.075 \%$ and vanillic acid / $0.086 \%$ ) in extract (No.1), (xanthotoxin / 54.925 $\%$, imperatorin / $0.619 \%$, quercetin / $0.118 \%$, hydroquinone / $1.607 \%$, catechol / $0.916 \%$ and salicylic acid / $41.917 \%$ ) in extract (No.2), (xanthotoxin / $30.321 \%$, imperatorin / 5.372 $\%$, quercetin / $0.834 \%$, hydroquinone $/ 2.047 \%$, resorcinol / $0.221 \%$ and salicylic acid / $12.891 \%$ ) in extract (No.3), (xanthotoxin / $24.042 \%$, imperatorin / $6.661 \%$, quercetin / $1.528 \%$, hydroquinone / $5.873 \%$, resorcinol / $0.623 \%$, salicylic acid / $12.302 \%$ and vanillic acid /1.020 \%) in extract (No.4), (xanthotoxin / 18.333\%, imperatorin / $13.271 \%$, quercetin / $1.995 \%$, hydroquinone / $0.503 \%$, catechol / $2.530 \%$ and salicylic acid / 0.922 \%) in extract (No.5), (xanthotoxin / $41.811 \%$, imperatorin / $1.861 \%$, quercetin / $3.276 \%$, resorcinol / $5.784 \%$ and salicylic acid / $5.240 \%$ ) in extract (No.6), (xanthotoxin / 37.012\% , imperatorin / $3.076 \%$, quercetin / $36.350 \%$, resorcinol / $15.292 \%$ and salicylic acid / $34.014 \%$ ) in extract (No.7), (Al-Hadidi, 2012). Chemically, its seeds contain different active ingredients namely: xanthotoxin (up to $1.15 \%$ ), imperatorin (up to $0.75 \%$ ), and bergapten (up to $1.88 \%$ ). Other coumarins of significance are marmesin (up to $0.25 \%$ ), isoimperatorin $(0.01 \%)$, heraclenin $(0.07 \%)$ and isopimpinellin $(0.01 \%)$. Other constituents of interest are acetylated flavonoids (Singab, 1998); (Ivie, 1978); (Abu-Mustafa and Fayez, 1961).

Table (1) showed the antimicrobial activity of Ammi majus extracts against some pathogenic bacteria. For Staphylococcus aureus, the inhibitory effects were recorded in all Ammi majus extracts. A high inhibitory effect was noted in extract (No.7) with a zone of (20) $\mathrm{mm}$ while the least inhibitory effect was observed for extract (No.6) with a zone of (9) $\mathrm{mm}$. In Staphylococcus epidermidis, extract (No.7) exhibited more antibacterial effect with a zone of (23) $\mathrm{mm}$ and least effect was observed for both extracts (No.3 and 5) with a zone of (8) mm while the extracts (No.4 and 6) did not show any effect against Staphylococcus epidermidis Fig. (1). Escherichia coli, Proteus mirabilis and Proteus vulgaris bacteria were found to be resistant to all extracts except extract (No.7) with an inhibition zones of $(23,21,16) \mathrm{mm}$ respectively. Results showed a high concentration - activity relationship for the phenolic compounds (quercetin, resorcinol and salicylic acid) in extract (No.7) when compared with its concentrations in extract (No.6) which contained the same compounds nevertheless did not show any (or show little) antibacterial activity against the tested bacterial isolates, also the presence of vanillic acid in extract (No.4) may inhibited the antimicrobial activity of hydroquinone, while the little activity of both extracts (No.3 and 5 ) is due to the presence of hydroquinone alone or in combination with catechol against Staphylococcus epidermidis. Hirai and co-workers (2010) showed that quercetin exerted selective antibacterial activity against Staphylococcus aureus (by induced aggregation of Staphylococcus aureus cells), including methicillin-resistant Staphylococcus aureus (MRSA), and Staphylococcus epidermidis. Also quercetin inhibits super coiling activity of Escherichia coli bacterial gyrase by binding to the ATP binding site of gyrase B (Plaper et al., 2003). Previous studies have shown that the antimicrobial activity of catechol, salicylic acid and hydroquinone is enzyme inhibition by the oxidized compounds, thereby bind either 
directly to sulphydryl groups and inactivates the protein, or protein and glutathione radicals are produced. These radicals might subsequently lead to protein cross-linking and glutathione dimer formation (Stoyanovsky et al., 1995). Catechol alone does not cause oxidative DNA damage but in combination with hydroquinone (induces oxidative DNA damage alone), however, the 8-hydroxy- 20-deoxyguanisine level increases, which is indicative for the occurrence of oxidative DNA damage (Kolachana et al., 1993). Alvarez and co-workers (2006) postulated that binding of a flavonoid makes an easier passage of another flavonoid by diffusion across structural membrane proteins and as such, the binding of quercetin to porines change the tridimensional conformation thereby, exposuring the hydrophilic character of the pore. Mori and colleagues (1987) showed that DNA synthesis was strongly inhibited by flavonoids in Proteus vulgaris, whilst RNA synthesis was most affected in S. aureus as such, the B ring of the flavonoids plays a role in intercalation or hydrogen bonding with the stacking of nucleic acid bases.

Table 1: Antibacterial activity of Ammi majus extracts on some bacterial isolates (mm).

\begin{tabular}{|c|c|c|c|c|c|}
\hline \multirow[b]{2}{*}{$\begin{array}{c}\text { Ammi majus } \\
\text { extracts }\end{array}$} & \multicolumn{5}{|c|}{ Inhibition zones of some bacterial genera (mm). } \\
\hline & $\begin{array}{c}\text { Staphylococcus } \\
\text { aureus }\end{array}$ & $\begin{array}{c}\text { staphylococcus } \\
\text { epidermidis }\end{array}$ & $\begin{array}{c}\text { Escherichia } \\
\text { Coli }\end{array}$ & $\begin{array}{c}\text { Proteus } \\
\text { mirabilis }\end{array}$ & $\begin{array}{l}\text { Proteus } \\
\text { Vulgaris } \\
\end{array}$ \\
\hline Extract No.1 & $12(\mathrm{~S})$ & $15(\mathrm{~S})$ & $0(\mathrm{R})$ & $0(\mathrm{R})$ & $0(\mathrm{R})$ \\
\hline Extract No.2 & $15(\mathrm{~S})$ & $16(\mathrm{~S})$ & $0(\mathrm{R})$ & $0(\mathrm{R})$ & $0(\mathrm{R})$ \\
\hline Extract No.3 & $13(\mathrm{~S})$ & $8(\mathrm{~S})$ & $0(\mathrm{R})$ & $0(\mathrm{R})$ & $0(\mathrm{R})$ \\
\hline Extract No.4 & $11(\mathrm{~S})$ & $0(\mathrm{R})$ & $0(\mathrm{R})$ & $0(\mathrm{R})$ & $0(\mathrm{R})$ \\
\hline Extract No.5 & $12(\mathrm{~S})$ & $8(\mathrm{~S})$ & $0(\mathrm{R})$ & $0(\mathrm{R})$ & $0(\mathrm{R})$ \\
\hline Extract No.6 & $9(\mathrm{~S})$ & $0(\mathrm{R})$ & $0(\mathrm{R})$ & $0(\mathrm{R})$ & $0(\mathrm{R})$ \\
\hline Extract No.7 & $20(\mathrm{~S})$ & $23(\mathrm{~S})$ & $23(\mathrm{~S})$ & $21(\mathrm{~S})$ & $16(\mathrm{~S})$ \\
\hline
\end{tabular}

Sensitive (S), Resistance (R).

Table (2) showed the antimicrobial activity of the antibiotics against some pathogenic bacteria. Staphylococcus aureus and Staphylococcus epidermidis Fig. (2) were reported to show sensitivity to trimethoprim, ampicillin, penicillin and cephalothin respectively and resistance against cefotaxime. While Escherichia coli, Proteus mirabilis and Proteus vulgaris are more resistant to all the antibiotics used. Ampicillin made a great impact initially on both Gram positive and Gram negative pathogens while cephalothin had a powerful action against Gram positive bacteria but much less against anaerobes and certain Gram negative bacteria (Brumfitt and Hamilton-Miller, 1988). On the other hand, the antibiotic penicillin-G doesn't have any effect against isolated pathogenic bacterial organisms (Escherichia coli and Proteus mirabilis) which the percentage of resistant organism reached $(100.0 \%)$ followed by ampicillin $(88.0 \%)$ and cefotaxime sodium (86.0\%), (Ghaly et al., 2009). 
Table 2: Antibacterial activity of antibiotics on some bacterial isolates (mm).

\begin{tabular}{|c|c|c|c|c|c|}
\hline \multirow{2}{*}{ Antibiotics } & \multicolumn{5}{|c|}{ Inhibition zones of some bacterial genera (mm) } \\
\cline { 2 - 6 } & $\begin{array}{c}\text { Staphylococcus } \\
\text { aureus }\end{array}$ & $\begin{array}{c}\text { Staphylococcus } \\
\text { epidermidis }\end{array}$ & $\begin{array}{c}\text { Escherichia } \\
\text { Coli }\end{array}$ & $\begin{array}{c}\text { Proteus } \\
\text { mirabilis }\end{array}$ & $\begin{array}{c}\text { Proteus } \\
\text { Vulgaris }\end{array}$ \\
\hline Trimethoprim(TMP) & $23(\mathrm{~S})$ & $20(\mathrm{~S})$ & $0(\mathrm{R})$ & $0(\mathrm{R})$ & $0(\mathrm{R})$ \\
\hline Ampicillin (Am) & $21(\mathrm{~S})$ & $19.5(\mathrm{~S})$ & $0(\mathrm{R})$ & $0(\mathrm{R})$ & $0(\mathrm{R})$ \\
\hline Penicillin (P) & $13.5(\mathrm{~S})$ & $12(\mathrm{~S})$ & $0(\mathrm{R})$ & $0(\mathrm{R})$ & $0(\mathrm{R})$ \\
\hline Cephalothin (KF) & $12(\mathrm{~S})$ & $10.5(\mathrm{R})$ & $0(\mathrm{R})$ & $0(\mathrm{R})$ & $0(\mathrm{R})$ \\
\hline Cefotaxime (CTX) & $0(\mathrm{R})$ & $0(\mathrm{R})$ & $0(\mathrm{R})$ & $0(\mathrm{R})$ & $0(\mathrm{R})$ \\
\hline
\end{tabular}

Sensitive (S), Resistance (R).

Table (3) showed the interaction effects of Ammi majus extracts and antibiotics against some pathogenic bacteria. The best synergistic interactions showed trimethoprim, ampicillin, cephalothin (except extracts No.7 and 4) and penicillin (except extract No.7) with all Ammi majus extracts respectively against Staphylococcus aureus while cefotaxime with all Ammi majus extracts, penicillin with extract (No.7) and cephalothin with extract (No.7) showed antagonistic interactions and cephalothin with extract (No.4) showed indifferent interaction against the same bacteria. For Staphylococcus epidermidis, ampicillin with extracts (No.1,2,3,4,5,6) Fig. (3) , trimethoprim with extracts (No.1,2,3,4,5,6), cephalothin with extracts (No.3,4,5), cefotaxime with extracts (No.3,4,6) and penicillin with extracts (No.5,6) showed synergistic interactions, whereas penicillin with extracts (No.1,2,4,7), cephalothin with extracts (No.1,2,6,7) and cefotaxime with extracts (No.1,2,7) showed antagonistic interactions. Trimethoprim with extract (No.7), ampicillin with extract (No.7) Fig. (3), penicillin with extract (No.3) and cefotaxime with extract (No.5) showed indifferent interactions. In Escherichia coli, cephalothin with extracts (No.2,3,5,6), ampicillin with extracts (No.2,3,4,5) showed synergistic interactions, while trimethoprim, penicillin and cefotaxime with extracts (No.1,2,3,4,5,6), ampicillin with extracts (No.1,6) and cephalothin with extracts (No.1,4) showed indifferent interactions. Where as in Proteus mirabilis only cephalothin with extracts (No.2,3,5,6) showed synergistic interaction and (trimethoprim, ampicillin, penicillin and cefotaxime) with extracts (No.1,2,3,4,5,6), cephalothin with extracts (No.1,4) showed indifferent interactions. These results revealed that hydroquinone which is found in extracts (No.2-5) enhanced the activity of ampicillin with these extracts against Escherichia coli, while the presence of vanillic acid in both extracts $($ No.1,4) is responsible for the inactivity of cephalothin with these extracts against Escherichia coli and Proteus mirabilis. In Proteus vulgaris, ampicillin with extracts (No.1,2,3,4,5,6), trimethoprim with extracts (No.2,3,4,5,6) and cephalothin with extracts (No.2,3,4,6) showed synergistic interactions while penicillin and cefotaxime with extracts (No.1,2,3,4,5,6), cephalothin with extracts (No.1,5) and trimethoprim with extract (No.1) showed indifferent interactions. Results demonstrated that ampicillin activity with extract (No.1) may be due to the presence of vanillic acid in extract (No.1), while trimethoprim and cephalothin didn't show any antibacterial activity with extract (No.1) when compared with their activity in extract (No.4) which contained the same compounds in addition to the presence of hydroquinone. So, we suggested that 
hydroquinone diminished the inhibitory effect of vanillic acid against trimethoprim and cephalothin, and high concentration - activity relationship for salicylic acidin extract (No.2) with cephalothin against Proteus vulgaris. Whereas all antibiotics used with extract (No.7) against three bacteria showed antagonistic interactions. These results showed that phenolic compounds (salicylic acid, resorcinol and quercetin) in extract (No.7) have been found to be synergistic enhancers in that though they possess antimicrobial properties alone, but when used concurrently with antibiotics their activity inhibited by the antibiotics. The exact mechanism of the antimicrobial synergistic interaction occurred by the inhibition of bacterial cell wall synthesis which leads to lyses of the cells, might facilitate the influx of phenolic compounds such as quercetin and xanthotoxin into the bacterial cells, such higher concentrations in the cells will enhance the damage on DNA caused by quercetin which inhibits DNA polymerase- $\beta$ and xanthotoxin which binds preferentially to the guanine and cytosine moieties of DNA, leading to cross-linking of DNA, thus inhibiting DNA synthesis and function (Bennett and Brown, 2009); (Dewick, 2009); (Schinazi et al., 1997). Quercetin showed markedly enhanced antibacterial activity with antibiotics: oxacillin, ampicillin, vancomycin, gentamicin and erythromycin against Methicillin-Resistant S. aureus (MRSA), (Hirai et al., 2010). Phenolic acids like salicylic acid, p-anisic acid and caffeic acid have been shown to potentiate the activity of $\beta$ - lactam antibiotics against various strains of Staphylococcus aureus (Kwon et al., 2007); (Muroi et al., 2004). While the uptake of catechol-cephalosporins by Escherichia coli K-12 may be self-limiting ; a priori, periplasmic concentrations much in excess of those required to saturate the target PBP could be precluded by the attendant antibacterial effects of the transported substrate (Curtis et al., 1988).

In the present study, Gram positive bacteria are known to be more susceptible to Ammi majus extracts alone, antibiotics alone (except cefotaxime) and interaction between them than Gram negative bacteria. This generally higher resistance among Gram negative bacteria could be ascribed to the presence of their outer membrane, surrounding the cell wall, which restricts diffusion of phenolic compounds or / and antibiotics through its lipopolysaccharide covering. The absence of this barrier in Gram positive bacteria allows the direct contact of the phenolic compounds or/and antibiotics with the phospholipids bilayer of the cell membrane, causing either an increase of ion permeability and leakage of vital intracellular constituents, or impairment of the bacterial enzyme systems (Zhao et al. 2001). For instance, the cell wall of Gram-negative bacteria contains (15-20\%) polysaccharides and (10-20\%) lipid, whereas that of Gram-positive bacteria contains (35$60 \%$ ) polysaccharide and only (0-2\%) lipid and the cell membrane of Escherichia coli contains (20\%) lipid, whereas that of Staphylococcus aureus contains (2\%) lipid (Alli et al. 2011). The polysaccharide and lipid contents of the cell wall have an effect on the permeability to Ammi majus constituents or/and antibiotics; this may be responsible for the difference in susceptibility to Ammi majus extracts or/and antibiotics between Gram negative and Gram-positive bacteria. 
Table 3: Interaction effect between Ammi majus extracts and antibiotics on some bacterial isolates ( $\mathrm{mm})$.

\begin{tabular}{|c|c|c|c|c|c|}
\hline \multirow{2}{*}{$\begin{array}{c}\text { Ammi majus extracts }+ \\
\text { Antibiotics combination }\end{array}$} & \multicolumn{5}{|c|}{ Inhibition zones of some bacterial genera $(\mathrm{mm})$} \\
\hline & $\begin{array}{c}\text { Staphylococcus } \\
\text { aureus }\end{array}$ & $\begin{array}{c}\text { staphylococcus } \\
\text { epidermidis }\end{array}$ & $\begin{array}{c}\text { Escherichia } \\
\text { Coli }\end{array}$ & $\begin{array}{c}\text { Proteus } \\
\text { mirabilis }\end{array}$ & $\begin{array}{l}\text { Proteus } \\
\text { Vulgaris }\end{array}$ \\
\hline Extract No.1+ Trimethoprim & $26(\mathrm{~S})$ & $25(\mathrm{~S})$ & $0(\mathrm{I})$ & $0(\mathrm{I})$ & $0(\mathrm{I})$ \\
\hline Extract No.1+ Ampicillin & $23(\mathrm{~S})$ & $23.5(\mathrm{~S})$ & $0(\mathrm{I})$ & $0(\mathrm{I})$ & $8.5(\mathrm{~S})$ \\
\hline Extract No.1+ Penicillin & $14.5(\mathrm{~S})$ & $11(\mathrm{~A})$ & $0(\mathrm{I})$ & $0(\mathrm{I})$ & $0(\mathrm{I})$ \\
\hline Extract No.1+ Cephalothin & $16(\mathrm{~S})$ & $13.5(\mathrm{~A})$ & $0(\mathrm{I})$ & $0(\mathrm{I})$ & $0(\mathrm{I})$ \\
\hline Extract No.1+ Cefotaxime & $8(\mathrm{~A})$ & $9(\mathrm{~A})$ & $0(\mathrm{I})$ & $0(\mathrm{I})$ & $0(\mathrm{I})$ \\
\hline Extract No.2+ Trimethoprim & $25(\mathrm{~S})$ & $26(\mathrm{~S})$ & $0(\mathrm{I})$ & $0(\mathrm{I})$ & $8(\mathrm{~S})$ \\
\hline Extract No.2+ Ampicillin & $22(\mathrm{~S})$ & $25(\mathrm{~S})$ & $7.5(\mathrm{~S})$ & $0(\mathrm{I})$ & $8.5(\mathrm{~S})$ \\
\hline Extract No.2+ Penicillin & $18(\mathrm{~S})$ & $12(\mathrm{~A})$ & $0(\mathrm{I})$ & $0(\mathrm{I})$ & $0(\mathrm{I})$ \\
\hline Extract No.2+ Cephalothin & $21(\mathrm{~S})$ & $13(\mathrm{~A})$ & $10(\mathrm{~S})$ & $10(\mathrm{~S})$ & $11(\mathrm{~S})$ \\
\hline Extract No.2+ Cefotaxime & $9(\mathrm{~A})$ & $10(\mathrm{~A})$ & $0(\mathrm{I})$ & $0(\mathrm{I})$ & $0(\mathrm{I})$ \\
\hline Extract No.3+ Trimethoprim & $24.5(\mathrm{~S})$ & $23.5(\mathrm{~S})$ & $0(\mathrm{I})$ & $0(\mathrm{I})$ & $8(\mathrm{~S})$ \\
\hline Extract No.3+ Ampicillin & $23.5(\mathrm{~S})$ & $24(\mathrm{~S})$ & $8(\mathrm{~S})$ & $0(\mathrm{I})$ & $8.5(\mathrm{~S})$ \\
\hline Extract No.3+ Penicillin & $16.5(\mathrm{~S})$ & $12(\mathrm{I})$ & $0(\mathrm{I})$ & $0(\mathrm{I})$ & $0(\mathrm{I})$ \\
\hline Extract No.3+ Cephalothin & $17.5(\mathrm{~S})$ & $14(\mathrm{~S})$ & $9(\mathrm{~S})$ & $9(\mathrm{~S})$ & $10(\mathrm{~S})$ \\
\hline Extract No.3+ Cefotaxime & $10(\mathrm{~A})$ & $9(\mathrm{~S})$ & $0(\mathrm{I})$ & $0(\mathrm{I})$ & $0(\mathrm{I})$ \\
\hline Extract No.4+ Trimethoprim & $24(\mathrm{~S})$ & $23(\mathrm{~S})$ & $0(\mathrm{I})$ & $0(\mathrm{I})$ & $8(\mathrm{~S})$ \\
\hline Extract No.4+ Ampicillin & $23(\mathrm{~S})$ & $23.5(\mathrm{~S})$ & $7(\mathrm{~S})$ & $0(\mathrm{I})$ & $8(\mathrm{~S})$ \\
\hline Extract No.4+ Penicillin & $16(\mathrm{~S})$ & $11(\mathrm{~A})$ & $0(\mathrm{I})$ & $0(\mathrm{I})$ & $0(\mathrm{I})$ \\
\hline Extract No.4+ Cephalothin & $12(\mathrm{I})$ & $12.5(\mathrm{~S})$ & $0(\mathrm{I})$ & $0(\mathrm{I})$ & $9(\mathrm{~S})$ \\
\hline Extract No.4+ Cefotaxime & $8(\mathrm{~A})$ & $9.5(\mathrm{~S})$ & $0(\mathrm{I})$ & $0(\mathrm{I})$ & $0(\mathrm{I})$ \\
\hline Extract No.5+ Trimethoprim & $25.5(\mathrm{~S})$ & $24(\mathrm{~S})$ & $0(\mathrm{I})$ & $0(\mathrm{I})$ & $9(\mathrm{~S})$ \\
\hline Extract No.5+ Ampicillin & $23(\mathrm{~S})$ & $23(\mathrm{~S})$ & $7.5(\mathrm{~S})$ & $0(\mathrm{I})$ & $7.5(\mathrm{~S})$ \\
\hline Extract No.5+ Penicillin & $16.5(\mathrm{~S})$ & $13(\mathrm{~S})$ & $0(\mathrm{I})$ & $0(\mathrm{I})$ & $0(\mathrm{I})$ \\
\hline Extract No.5+ Cephalothin & $12.5(\mathrm{~S})$ & $12.5(\mathrm{~S})$ & $10(\mathrm{~S})$ & $10(\mathrm{~S})$ & $0(\mathrm{I})$ \\
\hline Extract No.5+ Cefotaxime & $9(\mathrm{~A})$ & $8(\mathrm{I})$ & $0(\mathrm{I})$ & $0(\mathrm{I})$ & $0(\mathrm{I})$ \\
\hline Extract No.6+Trimethoprim & $25(\mathrm{~S})$ & $25(\mathrm{~S})$ & $0(\mathrm{I})$ & $0(\mathrm{I})$ & $8(\mathrm{~S})$ \\
\hline Extract No.6+ Ampicillin & $22(\mathrm{~S})$ & $22(\mathrm{~S})$ & $0(\mathrm{I})$ & $0(\mathrm{I})$ & $7.5(\mathrm{~S})$ \\
\hline Extract No.6+ Penicillin & $16(\mathrm{~S})$ & $24(\mathrm{~S})$ & $0(\mathrm{I})$ & $0(\mathrm{I})$ & $0(\mathrm{I})$ \\
\hline Extract No.6+ Cephalothin & $13(\mathrm{~S})$ & $0(\mathrm{~A})$ & $9(\mathrm{~S})$ & $10(\mathrm{~S})$ & $10(\mathrm{~S})$ \\
\hline Extract No.6+ Cefotaxime & $0(\mathrm{~A})$ & $8(\mathrm{~S})$ & $0(\mathrm{I})$ & $0(\mathrm{I})$ & $0(\mathrm{I})$ \\
\hline Extract No.7+Trimethoprim & $24.5(\mathrm{~S})$ & $23(\mathrm{I})$ & $8(\mathrm{~A})$ & $0(\mathrm{~A})$ & $10(\mathrm{~A})$ \\
\hline Extract No.7+ Ampicillin & $22.5(\mathrm{~S})$ & $23(\mathrm{I})$ & $10(\mathrm{~A})$ & $0(\mathrm{~A})$ & $10(\mathrm{~A})$ \\
\hline Extract No.7+ Penicillin & $14(\mathrm{~A})$ & $18(\mathrm{~A})$ & $9(\mathrm{~A})$ & $0(\mathrm{~A})$ & $7.5(\mathrm{~A})$ \\
\hline Extract No.7+ Cephalothin & $16(\mathrm{~A})$ & $14.5(\mathrm{~A})$ & $11.5(\mathrm{~A})$ & $13(\mathrm{~A})$ & $14(\mathrm{~A})$ \\
\hline Extract No.7+ Cefotaxime & $9(\mathrm{~A})$ & $10(\mathrm{~A})$ & $0(\mathrm{~A})$ & $8(\mathrm{~A})$ & $10(\mathrm{~A})$ \\
\hline
\end{tabular}

Synergism (S), Antagonism (A), Indifference (I). 


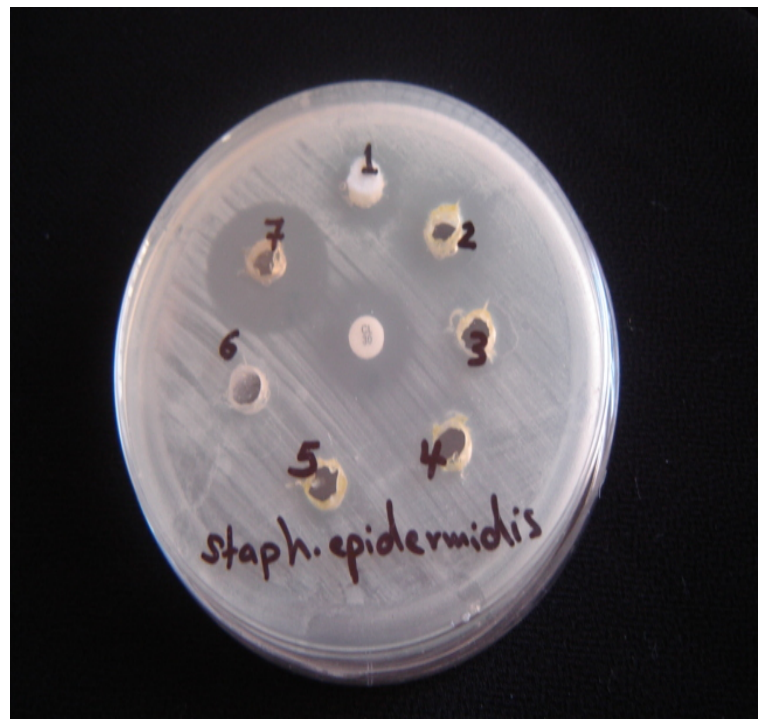

Fig. 1: Antibacterial activity of Ammi majus extracts on Staphylococcus epidermidis

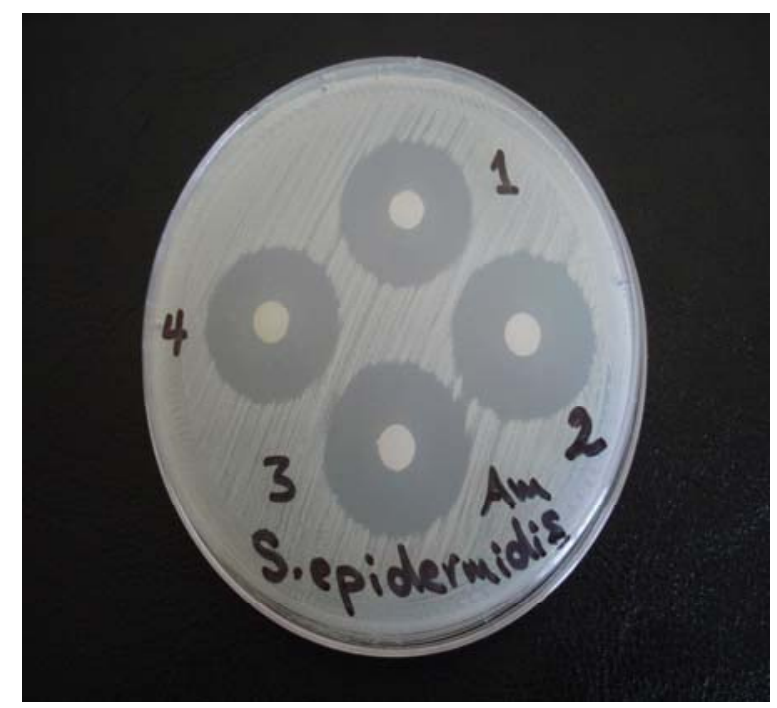

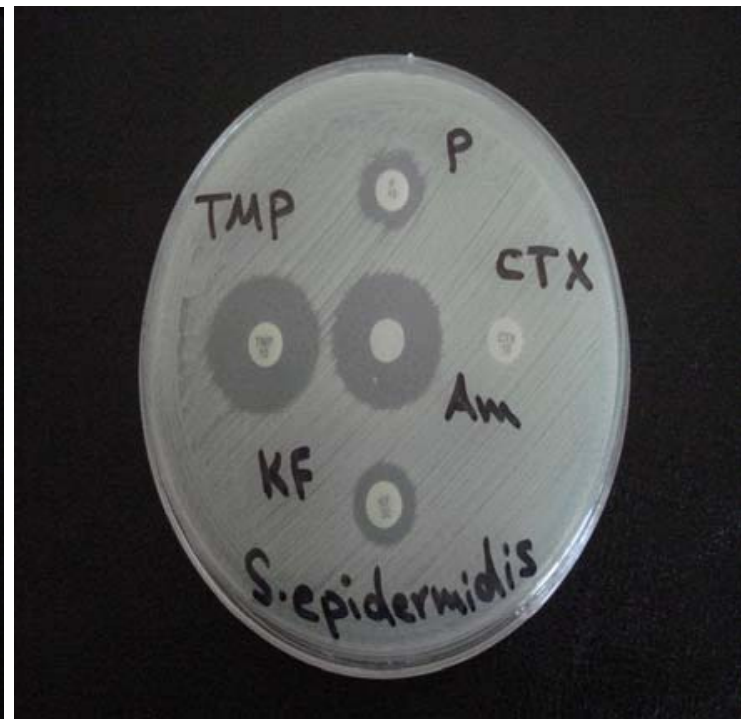

Fig. 2: Antibacterial activity of antibiotics on Staphylococcus epidermidis

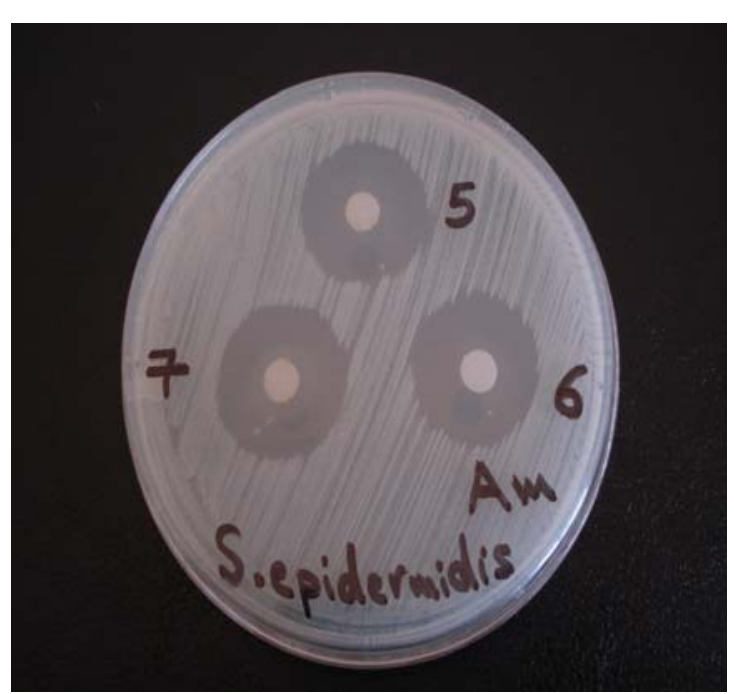

Fig. 3: Interaction effect between Ammi majus extracts with ampicillin on Staphylococcus epidermidis

\section{REFERENCES}

Abu-Mustafa, E. A.; Fayez, M. B. E. (1961). Natural coumarins. I. marmesin and marmesinin, further products from the fruits of Ammi majus L. J. Org. Chem., 26, 161-166.

Al-Hadidi, K. A. M. H. (2012). HPLC analysis of some phenolic compounds in Ammi majus herb (Khillah) extracts and study their effect on some pigments- producing strains of Pseudomonas aeruginosa. 10 th National Scientific Conference, College of Nursing, University of Mosul, pp. 501-515. 
Alli, J.A.; Boboye, B.E.; Okonko, I.O.; Kolade, A.F.; Nwanze, J.C. (2011). In-vitro assessments of the effects of garlic (Allium sativum) extract on clinical isolates of Pseudomonas aeruginosa and Staphylococcus aureus. Adv. Appl. Sci. Res., 2 (4), 25-36.

Alvarez, M. D. L. A.; Debattista, N. B.; Pappano, N. B. (2006). Synergism of flavonoids with bacteriostatic action against Staphylococcus aureus ATCC 25923 and Escherichia coli ATCC 25922. Biocell., 30 (1), 39-42.

Anonymous. (1985). "The Wealth of India - Raw Materials". Vol. I-A. Council of Scientific and Industrial Research, New Delhi, India, pp. 272-275.

Bancroft, E. A. (2007). Antimicrobial resistance: It's not just for hospitals. JAMA - J. Am. Med. Assoc., 298 (15), 1803-1804.

Bauer, A. W.; Kirby, W. M. M.; Sherris, J. C.; Turch, M. (1966). Antibiotic susceptibility testing by a standardized single disc method. Am. J. Clin. Pathol., 45, 494-496.

Bennett, P. N.; Brown, M. J. (2009). "Clinical Pharmacology". 10th ed. Churchill Livingstone Elsevier, pp. 188-195.

Brumfitt, W.; Hamilton-Miller, J. M. T. (1988). The changing face of chemotherapy. Postgraduate Med. J., 64, 552-558

Curtis, N. A. C.; Eisenstadt, R. L.; East, S. J.; Cornford, R. J.; Walker, L. A.; White, A. J. (1988). Iron-regulated outer membrane proteins of Escherichia coli K-12 and mechanism of action of catechol-substituted cephalosporins. Antimicrob. Agents Chemother., 32 (12), 1879-1886.

Dewick, P. M. (2009). "Medicinal Natural Products. A Biosynthetic Approach". 3rd ed. A John Willey and Sons, Ltd.. United Kingdom, pp. 163-165.

Ghaly, M. F.; Shalaby, M. A.; Shash, S. M. S.; Shehata, M. N.; Ayad, A. A. (2009). Synergistic effect of antibiotics and plant extract to control clinical bacterial isolates implicated in urinary tract infections. J. Appl. Sci. Res., 5 (10), 1298-1306.

Gibbons, S. (2004). Anti-staphylococcal plant natural products. Nat. Prod. Rep., 21, 263277.

Grand, A. ; Wondergem, P. A. ; Verpoorte, R.; pousset, J. L. (1988). Anti-infections phytotherapies of the tree-savannah of Senegal (West - Africa) II. Antimicrobial activity of 33 species. J. Ethnopharmacol., 22 (1), 25-31.

Gunics, G.; Farkas, S.; Motohashi, N.; Shah, A.; Harsukh, G.; Kawase, M.; Molnár, J. (2006). Interaction between 3,5-diacetyl-1,4-dihydropyridines and ampicillin, and erythromycin on different E. coli strains. In Vivo., 20 (3), 367-372.

Gurib-Fakim, A. (2006). Medicinal plants: traditions of yesterday and drugs of tomorrow (electronic version). Mol. Aspects Med., 7 (1), 1-93.

Harborne, J. B. (1973). " Phytochemical Methods: A Guide to Modern Techniques of Plant Analysis ". 1 st ed. Chapman and Hall Ltd. London, pp. 49-188.

Hirai, I.; Okuno, M.; Katsuma, R.; Arita, N.; Tachibana, M.; Yamamoto, Y. (2010). Characterisation of anti-Staphylococcus aureus activity of quercetin. Inter. J. Food Sci. Technology., 45 (6), 1250-1254.

Ivie, G.W. (1978). Linear furocoumarins (psoralens) from the seed of Texas Ammi majus L. (bishop's weed). J. Agricultural Food Chem., 26, 1394-1403. 
Kolachana, P.; Subrahmanyam, V. V.; Meyer, K. B.; Zhang, L.; Smith, M. T. (1993). Benzene and its phenolic metabolites produce oxidative DNA damage in HL60 cells in vitro and in the bone marrow in vivo. Can. Res., 53, 1023-1026.

Kumar, A. (1988). Cultivation and utilization of Ammi majus: a review. Current Res. Med. Aromat P1., 10 (1), 34-39.

Kwon, Y. I.; Apostolidis, E.; Labbe, R. G.; Shetty, K. (2007). Inhibition of Staphylococcus aureus by phenolic phytochemicals of selected clonal herbs species of Lamiaceae family and likely mode of action through proline oxidation. Food Biotechnol., 21 (1), 71-89.

Lu, Y.; Zhao, Y. P.; Wang, Z. C.; Chen, S. Y.; Fu, C. X. (2007). Composition and antimicrobial activity of the essential oil of Actinidia macrosperma from China. Nat. Prod. Res., 21, 227-233.

Manos, J.; Belas, R. (2006). The genera Proteus, Providencia and Morganella. Prokaryotes., 6, 245-269.

Mobley, H. L.; Warren, J. W. (1987). Urease-positive bacteriuria and obstruction of longterm urinary catheters. J. Clin. Microbiol., 25, 2216-2217.

Mori, A.; Nishino, C.; Enoki, N.; Tawata S. (1987). Antibacterial activity and mode of action of plant flavonoids against Proteus vulgaris and Staphylococcus aureus. Phytochem., 26, 2231-4.

Morimoto, I.; Kishi, T.; Ikegami, S.; Hirata, Y. (1965). Naphthoquinone derivatives from Lithospermum erythrohizon siebold et zuccarini. Tetrahedron Lett., 6 (52), 4737 4739.

Muroi, H.; Nihei, K.; Tsujimoto, K.; Kubo, I. (2004). Synergistic effects of anacardic acids and methicillin against methicillin resistant Staphylococcus aureus. Bioorg. Med. Chem., 12 (3), 583-587.

Olson, M. E.; Ceri, H.; Morck, D. W.; Buret, A. G.; Read, R. R. (2002). Biofilm bacteria: formation and comparative susceptibility to antibiotics. Can. J. Vet. Res., 66, 86-92.

Plaper, A.; Golob, M.; Hafner, I.; Oblak, M.; Solmajer, T.; Jerala; R. (2003). Characterization of quercetin binding site on DNA gyrase. Biochem. Biophys. Res. Commun., 306, 530-536.

Rani, A.; Jain, S.; Dureja, P.; Kumar, R.; Kumar, A. (2009). Synergistic interaction between synthetic and natural products: a promising tool for the development of environmentally safe potent antimicrobial agents. World Appl. Sci. J., 5, 59-63.

Saeed, M. A.; Khan, F. Z. (1994). Studies on the contact dermatitic properties of Indigenous Pakistani medicinal Plants. J. Faculty Pharm. Gazi. Univer., 11(1), 17-24.

Schinazi, R. F.; Hughes, S. H.; Chen, F. C. (1997). In vitro anti-HIV activity of biflavonoids isolated from Rhus succedanea and Garcinia multiflora. J. Nat. Prod., 60, 884-888.

Singab, A. N. B. (1998). Acetylated flavonol triglycosides from Ammi majus L. Phytochem., 49, 2177-2180.

Singh, G.; Maurya, S.; Delampasona, M. P.; Catalan, C. A. (2007). A comparison of chemical, antioxidant and antimicrobial studies of cinnamon leaf and bark volatile oils, oleoresins and their constituents. Food Chem. Toxico., 45, 1650-1661.

Sotto, A. C.; DE Boever, M.; Fabbro-Peray, P.; Gouby, A.; Sirot, D.; Jourdan, J. (2001). Risk factors for antibiotic resistant Escherichia coli isolated from hospitalized 
patients with urinary tract infections: a prospective study. J. Clin. Microbiol., 39 (2), 438444.

Srinivasan, D.; Nathan, S.; Suresh, T.; Lakshmanaperumalsamy, P. (2001). Antimicrobial activity of certain Indian medicinal plants used in folkloric medicine. $J$. Ethnopharmacol., 74, 217-220.

Stewart, P. S.; Costerton, J. W. (2001). Antibiotic resistance of bacteria in biofilms. Lancet., 358 (9276), 135-138.

Stoyanovsky, D. A.; Goldman, R.; Claycamp, H. G.; Kagan, V. E. (1995). Phenoxyl radicalinduced thiol-dependent generation of reactive oxygen species: Implications for benzene toxicity. Arch. Biochem . Biophys., 317, 315-323.

Tsankova, E. T.; Dyulgerov, A. S.; Milenkov, B. K. (1993). Chemical composition of the Bulgarian sumac oil. J. Essent. Oil Res., 5 (2), 205-207.

Zhao, W. H.; Hu, Z. O.; Okubo, S.; Hara, Y.; Shimamura, T. (2001). Mechanism of synergy between epigallocatechin gallate and $\beta$-lactams against methicillin resistant Staphylococcus aureus. Antimicrob. Agents Chemother., 45, 1737-1742. 